WORKING PAPER \#430

INDUSTRIAL RELATIONS SECTION

PRINCETON UNIVERSITY

FEBRUARY, 2000

\title{
Agents with and without Principals
}

\author{
Marianne Bertrand Sendhil Mullainathan*
}

January 14,2000

Who sets CEO pay? Our standard answer to this question has been shaped by principal agent theory: shareholders set CEO pay. They use pay to limit the moral hazard problem caused by the low ownership stakes of CEOs. Through bonuses, options, or long term contracts, shareholders can motivate the CEO to maximize firm wealth. In other words, shareholders use pay to provide incentives, a view we refer to as the contracting view.

An alternative view, championed by practitioners such as Crystal (1991), argues that CEOs set their own pay. They manipulate the compensation committee and hence the pay process itself to pay themselves what they can. The only constraints they face may be the availability of funds or more general fears, such as not wanting to be singled out in the Wall Street Journal as being overpaid. We refer to this second view as the skimming view. In this paper, we investigate the relevance of these two views.

\section{The Effect of Takeover Threats on CEO Pay}

We begin with some illustrative findings from an earlier paper (Bertrand and Mullainathan, 1999a). In the mid 1980s, several US states passed legislation making hostile takeovers more difficult. These laws very likely reduced the power of an important disciplining mechanism, the threat of being taken over in case of

*Bertrand: Department of Economics, Princeton University, CEPR and NBER; Mullainathan: Department of Economics, Massachusetts Institute of Technology and NBER. e-mail: mbertran@princeton.edu and mullain@mit.edu. Address: Marianne Bertrand, A-17-J-1, Industrial Relations Section, Firestone Library, Princeton University, Princeton, NJ 08540, USA; Sendhil Mullainathan, E52-380a, Department of Economics, MIT, 50 Memorial Drive Cambridge, MA 02142, USA. We thank our discussant, George Baker, for many helpful comments. 
poor management. How do we expect CEO pay to respond to this change in the legal environment? In the contracting model, where shareholders set CEO pay, the main effect of the anti-takeover laws should be on pay for performance. Shareholders, seeing the weakening of one disciplining mechanism, should respond by strengthening another, pay for performance. In the skimming model, on the other hand, the main effect should be on mean pay. CEOs facing a reduced threat of a hostile takeover can now skim more resources from their firm.

In Bertrand and Mullainathan (1999a), using panel data on about 600 firms between 1984 and 1991, we study the impact of the legislative changes on the level of CEO pay and its sensitivity to performance. We focus on the adoption by states of Business Combination Statutes. These statutes impose a moratorium period ( 3 to 5 years) on specified transactions between the target and a raider holding a certain threshold percentage of stock unless the board votes otherwise. They were adopted by several states at different times through the 1980s and early 1990s. The staggering of the laws over time allows us to identify the effect of the laws after controlling for year and firm fixed effects.

For the full sample, we found an increase in mean pay and an increase in pay for performance (especially for accounting measures of performance). These results are intriguing because they are consistent with both views of CEO pay. Mean pay rises as the skimming model would have predicted but pay for performance also rises as the contracting model would have predicted.

To help resolve this ambiguity, we look more closely at which firms experienced the increases in mean pay and in pay for performance. We focus on how firms with different corporate governance are affected by the new laws. More specifically, we separate the firms in our sample into two groups based on whether the firm has a large shareholder present or not. Large shareholders are very often thought to be an effective governance mechanism and are an easy way to measure corporate governance given the available data (Shleifer and Vishny, 1986). We define a large shareholder as an owner who has a block of at least five percent of common shares in the sample base year. Blocks that are owned by the CEO are, of course, excluded.

Table 1 reports our findings for mean pay. The dependent variable is the logarithm of total CEO compensation. Each regression includes, in addition to a dummy variable for the adoption of a Business 
Combination Statute, year fixed effects, firm fixed effects, a quadratic in CEO age, a quadratic in CEO tenure, the logarithm of total assets and the logarithm of total employment.

Column (1) focuses on firms with a large shareholder. In these firms, we see a statistically insignificant increase in mean pay of only $2 \%$ following the laws. Column (2) focuses on firms without a large shareholder. For these firms, in contrast, CEO pay grew by (this time a statistically significant) $7.5 \%$. The increase in mean pay was actually quite heterogeneous. While firms without a large shareholder experienced a large increase, firms with a large shareholder experienced almost no increase.

In Table 2, we similarly break apart the pay for performance results. Here we find the opposite effect. The increase in the sensitivity of pay to accounting performance is concentrated among the firms with a large shareholder. Firms without one show no increase in pay for performance.

We have just shown that in response to the passage of anti-takeover legislation, firms with a large shareholder increased pay for performance, while firms without a large shareholder increased mean pay. This suggest that the two models of CEO pay need not be contrasted. Instead, they may both be true and indeed may be quite complementary. This intuition is reinforced in the additional tests that follow.

\section{Further Evidence}

\section{II.1 Are CEOs Rewarded for Luck?}

In Bertrand and Mullainathan (1999b), we find two further pieces of evidence. In the first test, we examine whether CEOs are rewarded for observable luck. By luck we mean changes in firm performance that are beyond the CEO's control. In simple agency models, pay should not respond to luck since by definition the CEO cannot influence luck. Tying pay to luck doesn't provide better incentives (the CEO can't change luck), but merely adds risk to the contract (Holmstrom, 1979). Under the skimming view, on the other hand, pay will be correlated with luck since the CEO can use lucky dollars to pay herself more.

To empirically examine the responsiveness of pay to luck, we use three different measures of luck. First, we perform a case study of oil extracting firms where large movements in oil prices tend to affect firm 
performance on a regular basis. Second, we use changes in industry-specific exchange rate for firms in the traded goods sector. Third, we use year-to-year differences in mean industry performance to proxy for the overall economic fortunes of a sector. For all three measures, we find that CEO pay responds to luck. In fact we find that, for all three luck measures, CEO pay is as sensitive to a "lucky dollar" as to a "general dollar."

Most importantly, we find that CEO pay responds less to luck in the better governed firms. Similarly to our takeover results, we find that the presence of a large shareholder reduces the amount of pay for luck. Qualitatively equivalent results hold for other governance measures such as the level of CEO entrenchment (measured as CEO tenure interacted with the presence of a large shareholder) and board size. Again, improved governance leads to greater concordance with the contracting view, while weakened governance leads to greater concordance with the skimming view.

\section{II.2 Are Stock Options Grants Gifts?}

The second test presented in Bertrand and Mullainathan (1999b) focuses on the granting of stock options. Contract theory predicts that when stock options are granted, other components of pay should be adjusted down so that CEOs are left indifferent between the pay package containing options and the one containing no options. Supporters of the skimming view, on the other hand, would highlight the fact that stock options do not appear on balance sheets. Because of accounting rules, firms do not charge their earnings for the options they grant. CEOs can therefore pay themselves through option grants without affecting the company's bottom line. If shareholders mainly look at this bottom line, options grants are an easy way to skim without drawing unwanted attention. Thus, the CEO who gives herself options would not need to lower the other components of pay at all. Thus, while contracting predicts a charge for options, skimming predicts little charge.

In the empirical test, we focus on the question of how the strength of governance in the firm affects the charge for options. Using the same governance measures as in the previous test, we find that poorly governed CEOs are charged less for their new options grants. For example, when there is no large shareholder sitting 
on the board, the CEO is charged less for each dollar's worth of options granted. Again, we find greater resemblance to skimming in the poorly governed firms.

\section{An Independent Test}

The above findings point towards the coexistence of skimming and agency models. In this section, we provide another independent test of this idea by revisiting the evidence in Aggarwal and Samwick (1999). Aggarwal and Samwick's paper starts with the following important prediction of the contracting model: the sensitivity of pay to performance should decrease as the riskiness or variance of performance increases. In support of that prediction, Aggarwal and Samwick find that the sensitivity of pay to performance is larger in firms with less volatile stock prices.

In the context of what we have shown before, a natural question arises: Does the tradeoff between performance volatility and pay-performance sensitivity appear stronger in the better governed firms? We test this hypothesis using a CEO compensation data that covers 792 different corporations over the 1984-1991 period, provided to us by David Yermack. Compensation data was collected from the corporations' SEC Proxy, 10-K, and 8-K filings. Other data was transcribed from the Forbes magazine annual survey of CEO compensation as well as from SEC Registration statements, firms' Annual Reports, direct correspondence with firms, press reports of CEO hires and departures, and stock prices published by Standard \& Poor's. Firms were selected into the sample on the basis of their Forbes rankings. Forbes magazine publishes annual rankings of the top 500 firms on four dimensions: sales, profits, assets and market value. To qualify for the sample a corporation must appear in one of these Forbes 500 rankings at least four times between 1984 and 1991. In addition, the corporation must have been publicly traded for four consecutive years between 1984 and 1991. While this data set covers a smaller set of companies than the Execucomp database (used by Aggarwal and Samwick), it does contain some information on the structure of corporate ownership, which is not available in Execucomp.

The dependent variable, total CEO compensation, is defined as the sum of salary, bonus, other compensa- 
tion and the value of options granted in that year. It is a measure of flow compensation. Unlike Execucomp, Yermack's data does not contain information on the value of stock options and equity shares held by CEOs. In practice, we use the logarithm of total compensation. We use the real rate of return to shareholders (percentage change in the real value of shareholder wealth, including dividend payments) as our measure of performance.

Our risk measure is based on the sample variance of daily stock returns for the last 120 days of the fiscal year. Following Aggarwal and Samwick, we use the cumulative distribution function (CDF) of the variance of returns in the sample as our risk measure. The smallest observed variance in the sample has a CDF value of 0 ; the largest observed variance has a CDF value of 1.

We follow Bertrand and Mullainathan (1999a) and split our original sample into two subsamples of firms based on whether or not they have at least one block of at least five percent of common shares in the sample base year (1984), whether the block holder is or is not a director. As before, we exclude blocks that are owned by the CEO.

The results for the full sample, not reported here, match the findings in Aggarwal and Samwick (1999). CEO pay becomes less sensitive to the rate of return to shareholders as the volatility of stock returns increases. In Table 3, we show how the presence of a large shareholder mediates these findings. Regressions are estimated by OLS. Each regression contains as independent variables the performance measure, the risk measure and the interaction of performance with risk. This interaction term is what allows us to understand the effect of risk on the pay to performance sensitivity. In addition, we include firm fixed effects, year fixed effects, a quadratic in CEO age and a quadratic in CEO tenure (but do not report these coefficients in the Table).

Column (1) focuses on firms with a large shareholder present. Here we find support for the contracting model. Higher variance means lower pay for performance sensitivity. Column (2) focuses on the firms where there is no large shareholder present. For this group, there is no relationship: the pay for performance sensitivity does not depend on the riskiness of the stock. Hence the existing finding that the variance of performance affects the sensitivity of pay to performance appears to be coming from the better governed 
firms in the sample.

\section{Synthesizing the Empirical Findings}

We have so far laid out a set of empirical facts that support the general claim that better governed firms behave according to the contracting model while worse governed ones behave according to the skimming model. A key to moving forward will be to develop a model that is consistent with all these facts.

A very first concern that needs to be addressed is whether our findings represent a spurious relationship. The apparent correlation between the use of optimal CEO compensation contracts and the presence of large shareholders might not reflect a true direct relationship. Instead, skimming and weak governance might be related to each other through some third factor that we are not observing or are not adequately controlling for. But what could this third factor be? Firm size might be one example. Owning 5 percent of the shares of a large firm is more expensive so that large firms typically have less large shareholders. We can, of course, appropriately control for size in the above tests and when we did so the results did not change. The deeper question, however, is why a third factor (such as size) would consistently lead to the pattern of responses that we see. For example, why would larger firms (which would be correlated with poorer governance) respond to takeover legislation with greater mean pay and less pay for performance increases, reward their CEOs more for luck, charge their CEOs less for options and not account for variance in choosing the pay for performance sensitivity? If it is not because of poorer governance, then why? It is always a possibility that some unobserved factor drives our results. We simply find it hard to point to any such factor that would intuitively match the consistent patterns that we observe.

Assuming that these results are indeed about governance, the simplest way to explain them seems to be through a bargaining model. Suppose shareholders and the CEO bargain over the pay package. Skimming could then be modeled as the case where the CEO has much or all of the bargaining power. Contracting would be the case where shareholders have much or all of the power. Such a bargaining model would also have the added feature of being able to deal with a continuum of possibilities between skimming and contracting. 
While intuitively appealing, this model cannot match the results above. To see why, note that the Coase Theorem applies in this model. The bargaining power of the CEO will only determine how much average pay she gets, not the structure of her contract. A CEO with more bargaining power will not choose to get more pay for luck. She will also have luck shocks removed from her pay but will simply expect a higher average compensation. Similarly, there is no reason that she would want to be charged less for options grants. She will want to face the same charge for options but merely take a bigger compensation package overall. More generally, the optimal contract will always be chosen with bargaining power simply determining the division of rents between the shareholders and the CEO.

An alternative modeling approach could be to focus on the superior monitoring technology of large shareholders. Our findings could be the result of an optimal contracting process where principals always set pay, whether governance is weak or strong, but face different signal to noise ratios when evaluating CEO effort. In firms with large shareholders, principals can more easily separate CEOs' effort from other noisy movements in firm performance. Such a view could potentially explain why there is more pay for luck in firms without large shareholders. One would, however, need to assume that observing movements in oil prices or in aggregate industry shocks requires superior monitoring technology and cannot be done easily, for example by opening the business section of the daily newspaper.

The monitoring model cannot at all explain our findings on the impact of takeover threats. Why would principals in firms without large shareholders decide to give higher pay once CEOs are protected from hostile raiders? Their monitoring technology may be weaker but they still know the laws have been passed and should react to them. Similarly, the trade-off between incentive pay and variance of pay are equally puzzling. If anything, it is the principals of the well governed who should care less about stock market price volatility since they have access to better signals of effort. As a whole, it is hard to imagine how differences in monitoring alone could explain the array of results.

Thus our findings suggest that governance is not just about increased bargaining power or better monitoring. Instead, they suggest that governance is about who has effective control. In contracting models, we always assume that some metaphorical principal controls the pay process. Even when governance is 
weak, this principal still sets pay (perhaps taking into account a worse monitoring technology). Our results suggest that a better model of governance would be one that recognizes that good governance is what allows shareholders to maintain effective control of, for example, the pay process.

To be concrete, consider the details of the pay process. In practice, CEO pay is usually set via the compensation committee. This committee may cater to the interests of the CEO or of the shareholders. When governance is good, such as when there is a large shareholder present, this committee may make sure that the pay package looks optimal from the shareholders' perspective. The committee will respond to the passage of takeover legislation, or will be more reluctant to raise the CEO's bonus just because oil prices rose and so on.

When governance is weak, however, this committee may be much more willing to cater to the CEO. How does the committee set pay then? Even though the CEO has de facto control of this committee, she still faces constraints. The committee may be quite reluctant to attract the attention of shareholders or of other important constituencies, such as labor unions or the business press. This places constraints not just on how much can be skimmed but also on how skimming will take place. For example, more can be skimmed when firms' performance is high as shareholders may be paying even less attention to the firm. Pay for luck then naturally arises. Also, if shareholders mostly pay attention to their company's bottom line, the compensation committee will grant relatively more stock options as they are not charged directly against earnings.

\section{Conclusion}

This discussion highlights a set of open questions as we move forward from the empirical regularities above. First, we need to better understand what happens when the CEO has gained de facto control of the pay process. What are the real constraints on pay setting? This will require a more rigorous formalization of the skimming view. Second, we need to reinterpret what corporate governance actually does. We need to reconceptualize governance as the transfer of de facto control of important decisions from the CEO to the 
shareholders. Such a reconceptualization will have applications beyond executive compensation. Take for example the decision by firms to adopt takeover protection such as poison pills. Should we think this decision is made with the interests of shareholders or management in mind? This question is somewhat analogous to whether we think CEO pay is the result of optimal contracting or skimming. Perhaps governance plays a central role in this application too, with well governed firms using poison pills to raise bargaining power during takeover attempts and poorly governed firms using poison pills to entrench management. This final example highlights the broader value of a reconceptualization of good governance as being what gives CEOs principals. 


\section{References}

Aggarwal, Rajesh and Samwick, Andrew. "The Other Side of the Trade-off: The Impact of Risk on Executive Compensation." Journal of Political Economy, February 1999, 107(1), pp. 65-105.

Bertrand, Marianne and Mullainathan, Sendhil. "Corporate Governance and Executive Compensation? Evidence from Takeover Legislation." Mimeo, Princeton University, 1999a.

Bertrand, Marianne and Mullainathan, Sendhil. "Do CEOs Set Their Own Pay? The Ones Without Principals Do." Mimeo, Princeton University, 1999b.

Crystal, Graef. In Search of excess: The Overcompensation of American Executives. New York: W.W. Norton Co., 1991.

Holmstrom, Bengt. "Moral Hazard and Observability." Bell Journal of Economics, Spring 1979, 10(1), pp. 74-91.

Shleifer, Andrei and Vishny, Robert. "Large Shareholders and Corporate Control." Journal of Political Economy, June 1986, 94(3), pp. 461-488. 


\section{Table 1 - The Impact Anti-Takeover Legislation on CEO Pay: The Role of Large Shareholders ${ }^{a}$}

Dependent Variable: Log of Total CEO Compensation

\begin{tabular}{lcc} 
& $(1)$ & $(2)$ \\
Large Shareholder? & Yes & No \\
& & \\
Anti-Takeover Law Adopted & .026 & $.075^{* *}$ \\
& $(.040)$ & $(.031)$ \\
& & \\
Adjusted $R^{2}$ & .633 & .768 \\
Sample Size & 2281 & 2268 \\
\hline
\end{tabular}

${ }^{a}$ Notes:

1. "Large Shareholder" is a dummy variable that equals 1 ("Yes") if the firm has a strictly positive number of blocks of at least five percent of common shares in the base year (1984), whether the block holder is or is not a director. Blocks of at least five percent that are owned by CEOs are excluded.

2. "Anti-Takeover Law Adopted" is a dummy variable that equals 1 after the adoption of an anti-takeover law (Business Combination Statute) by the state the firm is incorporated in.

3. Each regression includes as controls year fixed effects, firm fixed effects, a quadratric in CEO age, a quadratic in CEO tenure, the logarithm of total assets and the logarithm of total employment.

4. ${ }^{* *}$ denotes significance at the $5 \%$. 
Table 2-The Impact of Anti-Takeover Legislation on Pay for Performance: The Role of Large Shareholders ${ }^{a}$

Dependent Variable: Log Total CEO Compensation

$\begin{array}{lcc}\text { Large Shareholder? } & (1) & (2) \\ & \text { Yes } & \text { No } \\ \text { Anti-Takeover Law Adopted } & .017 & .085^{* * *} \\ & (.040) & (.030) \\ & & .316 \\ \text { Anti-Takeover Law Adopted } & 1.126^{* *} & (.584) \\ \text { Acc. Rate of Return } & (.582) & 2.533^{* * *} \\ \text { Acc. Rate of Return } & 2.352^{* *} & (1.08) \\ & (1.116) & \\ & & .782 \\ \text { Adjusted } R^{2} & .641 & 2268 \\ \text { Sample Size } & 2281 & \end{array}$

Notes:

1. "Large Shareholder" is defined as in Table 1.

2. "Anti-Takeover Law Adopted" is defined as in Table 1.

3. Accounting Rate of Return is the ratio of Net Income over Total Assets. It has been demeaned.

4. Each regression includes as controls year fixed effects, accounting rate of return interacted with year fixed effects, firm fixed effects, a quadratric in CEO age, a quadratic in CEO tenure, the logarithm of total assets and the logarithm of total employment.

$5 .^{* *}$ denotes significance at the $5 \%{ }^{* * *}$ at the $1 \%$. 


\section{Table 3-The Impact of Risk on CEO Pay: The Role of Large Shareholders ${ }^{a}$}

Dependent Variable: Log of Total CEO Compensation

$\begin{array}{lcc}\text { Large Shareholder? } & \begin{array}{c}(1) \\ \text { Yes }\end{array} & \begin{array}{l}(2) \\ \text { No }\end{array} \\ \text { Performance } & \begin{array}{c}.003^{* * *} \\ (.000)\end{array} & \begin{array}{c}.001^{* * *} \\ (.000)\end{array} \\ & \begin{array}{l}.004^{* * * *} \\ \text { Performance* }\end{array} & .000 \\ \text { CDF of Variance } & (.001) & (.001) \\ \text { CDF of Variance } & -.07 & -.17^{* * *} \\ & (.06) & (.05)\end{array}$

Sample Size

2301

2025

${ }^{a}$ Notes:

1. "Large Shareholder" is defined as in Table 1.

2. "Performance" is defined as the real growth rate of shareholder wealth (including dividend payments) and is measured in percentage points.

3. Each regression includes as controls year fixed effects, firm fixed effects, a quadratic in CEO age and a quadratic in CEO tenure.

4. ${ }^{* * *}$ denotes significance at the $1 \% ;^{* * * *}$ at the $.1 \%$. 